\title{
Rabies virus in a pregnant naturally infected southern yellow bat (Lasiurus ega)
}

Allendorf SD (1), Albas A (2), Cipriano JRB (1), Antunes JMAP (1), Appolinário CM (1), Peres MG (1), da Rosa AR (3), Sodré MM (3), Megid J (1)

(1) Department of Veterinary Hygiene and Public Health, School of Veterinary Medicine and Animal Husbandry, São Paulo State University (UNESP - Univ Estadual Paulista), Botucatu, São Paulo State, Brazil; (2) São Paulo Agency of Agribusiness Technology, APTA, Presidente Prudente, São Paulo State, Brazil; (3) Chiropteran Sector, Zoonosis Control Center, São Paulo, São Paulo State, Brazil.

\begin{abstract}
Current knowledge on bat lyssavirus infections in their native hosts is limited and little is known about the virulence, virus dissemination and transmission among free-living insectivorous bats. The present study is a brief description of rabies virus (RABV) dissemination in tissues of a naturally infected pregnant southern yellow bat (Lasiurus ega) and its fetuses, obtained by reverse-transcriptase polymerase chain reaction (RT-PCR). The RT-PCR was positive in samples from the brain, salivary gland, tongue, lungs, heart, kidneys and liver. On the other hand, the placenta, three fetuses, spleen, intestine and brown fat tissue tested negative. This research demonstrated the absence of rabies virus in the fetuses, thus, in this specific case, the transplacentary transmission was not observed.
\end{abstract}

Key words: rabies, bats, vertical transmission, RT-PCR.

Rabies, a zoonosis that affects the central nervous system (CNS), provokes acute and fatal encephalitis in its mammal hosts. The etiologic agent of the disease is the rabies virus (RABV), a neurotropic RNA virus that belongs to the order Mononegavirales, family Rhabdoviridae, and genus Lyssavirus (1). Various mammals act as reservoirs for RABV in different parts of the world, particularly those from the orders Carnivora and Chiroptera (2). The mechanism by which rabies virus infections are maintained in bat populations remains poorly understood (3). Possible routes of transmission of the virus among bats include direct contact (bite), aerosol transmission, ingestion of virus-infected milk from an infected mother, and transplacental infection (4-8). Reports of natural transplacental transmission are rare and difficult to confirm. Such problems regarding bats received little attention (9). Sims et al. (8) reported rabies virus in the brain of one of 23 fetuses extracted from several female Mexican free-tailed bats (Tadarida brasiliensis), each of which had previously been inoculated via chest muscles with rabies virus (4). However, although transplacental transfer of rabies virus had been demonstrated in bats under laboratory conditions, it was suggested that prenatal infection of bats with rabies virus does not occur under natural conditions $(8,9)$.

The species herein studied, Lasiurus ega, belongs to the Vespertilionidae family and occurs from the southwestern United States to the south of Bolivia, Argentina, Paraguay, Uruguay and Trinidad (10). In Brazil, this specie is found in all Brazilian states of the central, south and southeastern regions; in Acre, Ceará, Pará, Pernambuco and Piauí states and also in the Amazon region (11). Although L. ega is generally thought of as a solitary animal, it occasionally shares the same roost (12). Even though it is not 
clear whether these bats are members of a social group or are simply individuals attracted to an optimal roost (13). L. ega most often roosts in trees, particularly among dead fronds of palm trees (14). The species has also been captured with relative frequency in natural and artificial shelters in urban areas (15-16). This bat species is a strong flyer and migrates toward the equator, as described in other species of the genus, which is particularly important on the spread of the virus to other regions (17-18).

In the present study, a female bat was found dead on the floor of a school located in Panorama city, in the western region of São Paulo state, Brazil, and taken to the laboratory. The brain of the bat was previously diagnosed as rabiespositive by means of fluorescent antibody test (FAT) and mouse inoculation test. Considering that the bat was pregnant and the need of more studies on rabies virus distribution among bats, the aim of the present study was to evaluate the presence of rabies virus in bat fetuses and in the female organs. The brain, salivary glands, tongue, lungs, heart, liver, spleen, kidneys, intestine, brown fat tissue, placenta and the three fetuses were collected as aseptically as possible using individual sterile instruments to avoid cross contamination. The stomach and urinary bladder could not be collected due to of the advanced state of degeneration of animal. The fetuses were separated into head and body.

Total RNA was extracted from the samples with TRIzol ${ }^{\circ}$ (Invitrogen, USA) according to the manufacturer's instructions. Challenge virus standard (CVS) was used as positive control and ultrapure water as negative control. To indentify rabies virus RNA in the samples a RT-PCR was performed as described by Soares et al. (19) using specific primers designed to amplify segments located in the middle of the $\mathrm{N}$ gene of RABV. RT-PCR products were run in 1.5\% agarose gel electrophoresis stained with ethidium bromide and observed under UV light and photographed. Fragments of 455 base pairs (bp) were observed.

In our study we did not find the virus in the placenta and fetuses since RT-PCR resulted negative in these samples. The virus was detected in the brain and salivary glands of the female bat and also in several organs such as tongue, lungs, heart, kidneys and liver. The spleen, intestine and brown fat tissue tested negative by RT-PCR.

The results obtained in this work corroborate other studies that investigated the vertical transmission of RABV in bats. In USA, nearterm fetuses of naturally-infected bats collected by the California Department of Public Health (from 1975 to 1985) also tested negative as well as newborns and older suckling bats recovered from the floor under a multimillion aggregation of bats in a Texas cave (9). In California, none of the 28 fetuses from 22 naturally infected bats was positive for rabies by either fluorescent antibody test (FAT) or suckling mouse inoculation tests, indicating that prenatal infection had not occurred. Similarly, in the Texan cave, none of the 284 suckling Mexican free-tailed bats (estimated to be less than 5 days old) presented rabies viral antigen in brain smears, but 76 of 395 bats (19.2\%) aged between 5 and 11 days were positive by FAT. Moreover, $84 \%$ of the 76 infected suckling bats were 7 to 11 days old, possibly infected at birth (9). Prenatal infection by rabies virus would seem less significant since newborn bats may acquire the infection at birth or shortly thereafter from infected mothers, other animals, or possibly by aerosols in highly populated caves (5).

Further studies involving more species are required to determine the occurrence of this type of transmission in bats infected with rabies virus, since information on routes of transmission of bat lyssaviruses may help to improve the understanding on the epidemiology of RABV and to develop actions to control rabies in these animals.

\section{ACKNOWLEDGEMENTS}

We thank Avelino Albas for kindly providing the bat for this study and for the previous diagnosis of rabies infection.

\section{COPYRIGHT}

(c) CEVAP 2011

\section{SUBMISSION STATUS}

Received: November 5, 2010.

Accepted: March 16, 2011.

Abstract published online: March 17, 2011.

Full paper published online: May 31, 2011.

\section{CONFLICTS OF INTEREST}

There is no conflict.

\section{FINANCIAL SOURCE}

The State of São Paulo Research Foundation 
(FAPESP) provided the financial grant (process number 05/59818-6).

\section{CORRESPONDENCE TO}

JANE MEGID, Departamento de Higiene Veterinária e Saúde Pública, Faculdade de Medicina Veterinária e Zootecnia, UNESP, Distrito de Rubião Júnior, $s / n$, Botucatu, SP, 18618-970, Brasil. Phone: +55 143811 6270. Fax: 55143811 6075. Email: jane@fmvz.unesp.br.

\section{REFERENCES}

1. Fauquet EM, Mayo MA, Maniloff J, Desselgerger $\mathrm{U}$, Ball LA. Virus taxonomy: classification and nomenclature of viruses. Eighth report of the International Committee on the Taxonomy of Viruses. Virus Taxonomy. $8^{\text {th }}$ ed. San Diego: Academic Press; 2005. p. 630-4.

2. Rupprecht CE, Hanlon CA, Hemachudha T. Rabies reexamined. Lancet Infect Dis. 2002;2(6):327-43.

3. Steece RS, Calisher CH. Evidence for prenatal transfer of rabies virus in the Mexican free-tailed bat (Tadarida brasiliensis mexicana). J Wildl Dis. 1989;25(3): 329-34.

4. Constantine DG, Solomon GC, Woodall DF. Transmission experiments with bat rabies isolates: responses of certain carnivores and rodents to rabies viruses from four species of bats. Am J Vet Res. 1968;29(1):181-90.

5. Constantine DG. Rabies transmission by air in bat caves. Public Health Service Publication. Washington, DC: Government Printing Office; 1967. p. 1617-51.

6. Constantine DG. Transmission experiments with bat rabies isolates: bite transmission of rabies to foxes and coyote by free-tailed bats. Am J Vet Res. 1966;27(116):20-3.

7. Constantine DG, Woodall DF. Transmission experiments with bat rabies isolates: reactions of certain Carnivora, opossum, rodents and bats to rabies virus of red bat origin when exposed to bat bite or by intramuscular inoculation. Am J Vet Res. 1966;27(116):24-32.

8. Sims RA, Allen R, Sulkin SE. Studies on the pathogenesis of rabies in insectivorous bats. III. Influence of the gravid state. J Infect Dis. 1963;112(1):17-27.
9. Constantine DG. Absence of prenatal infection of bats with rabies virus. J Wildl Dis. 1986;22(2):249-50.

10. Simmons NB. Order Chiroptera. In: Wilson DE, Reeder DM, editors. Mammal species of the world: a taxonomic and geographic reference. 3th ed. Baltimore: Johns Hopkins University Press; 2005. p. 312-529. 1 vol.

11. Tavares VC, Gregorin R, Peracchi AL. Sistemática: a diversidade de morcegos no Brasil. In: Pacheco SM, Marques RV, Esbérard CEL, editors. Morcegos do Brasil: biologia, sistemática, ecologia e conservação. Porto Alegre: Editora Armazém Digital; 2008. p. 25-8.

12. Barbour RW, Davis WH. Bats of America. Lexington: The University of Kentucky; 1969. 286.

13. Villa-R B. Los murciélagos de México. México: Instituto de Biologia, Universidad Nacional Autónoma de México; 1966. 491 p.

14. Spencer SG, Choucair PC, Chapman BR. Northward expansion of the southern yellow bat, Lasiurus ega in Texas. The Southwestern Naturalist. 1988;33(4):493.

15. Sodré MM, Rosa AR. Presença de morcegos insetívoros (Mammalia, Chiroptera) em abrigos artificiais, na cidade de São Paulo, Sudeste do Brasil. Anais do Congresso Sul-Americano de Mastozoologia; 2006; Gramado, RS. [Gramado, RS: publisher unknown]; 2006. 57 p.

16. Pacheco SM, Marques RV, Grillo HCZ, Marder E, Bianconi GV, Miretzski M, et al. Morcegos urbanos na Região Sul do Brasil. In: Pacheco SM, Marques RV, Esbérard CEL, editors. Morcegos do Brasil: biologia, sistemática, ecologia e conservação. Porto Alegre: Editora Armazém Digital; 2008. 415-26 p.

17. Kurta A, Lehr GC. Lasiurus ega. Mammalian Species. 1995;515(1):1-7.

18. Esbérard CEL, Moreira SC. Second record of Lasiurus ega (Gervais) (Mammalia, Chiroptera, Vespertilionidae) over the south Atlantic. Braz J Biol. 2006;66(1a): 185-6.

19. Soares RM, Bernardi F, Sakamoto SM, Heinemann MB, Cortez A, Alves LM, et al. A heminested polymerase chain reaction for the detection of Brazilian rabies isolates from vampire bats and herbivores. Mem Inst Oswaldo Cruz. 2002;97(1):109-11. 
Esteartigo sofreu alterações por solicitação do editor em 2011 conforme ERRATA publicada no Volume 17 Número 3 do periódico. (http://www.scielo.br/pdf/jvatitd/v17n3/18.pdf) 